\title{
THE ROLE OF THE CENTRAL ASIAN REGION IN CHINA'S NEW SILK ROAD ECONOMIC BELT PROJECT
}

Azhar SERIKKALIYEVA*

\begin{abstract}
In forty years of reform and implementation of open economy policies, great changes have taken place in China. With the country's high engagement with the world, it became obvious that China did not isolate itself from the global developments. The rapid growth of China's economy and the country's growing ties with the rest of the world necessitates the development of new concepts and approaches in the Chinese diplomacy. China's emerging role in the international arena triggers a change in current international political environment and causes further rebalancing of multipolar system. Therefore, strengthening multilateral cooperation with the other regional powers and international organizations provides suitable atmosphere for development. The study explores the key factors of interest for China in Central Asian states from the point of view of implementing its outside economic strategies.
\end{abstract}

Key Words: China, Central Asia, SCO, BRI, Foreign Policy.

\footnotetext{
* Research Fellow, Eurasian Research Institute, Mametova 48, Almaty 050004, Kazakhstan, e-mail: serikkaliyeva@gmail.com
} 


\section{INTRODUCTION}

Since China announced its reform and open-door up policy, the country had adopted a low profile foreign policy established by the late Deng Xiaoping. Under the leadership of Deng Xiaoping, China joined the world; with its continuous rise, it is expected by the world community to play a more important role in world affairs. Today China's grand diplomacy is featured by so-called "two fronts and one circle" strategy. The "two fronts" include a new type of great powers relationship with countries such as the US, Russia, India and major European countries, and the Belt and Road Initiative (BRI) which mainly deals with developing countries; thus, the "one circle" refers to peripheral diplomacy that is mainly related to China's Asian neighbors.

Announcement of the revival of the ancient Silk Road by the Chinese President Xi Jinping in Astana, the capital of Kazakhstan on September 7, 2013, signals underlying importance of the Central Asian countries for China and the potentially significant role played by the Eurasian region in China's much-ambitious and much talked about BRI. It was during President Xi Jinping's maiden visit to the Central Asian countries that he proposed to work closely with the Central Asian republics for jointly development the New Silk Road Economic Belt (NSREB). President Xi said that China-Central Asia should work to improve rail and road connectivity through development of strong networks of highways, airfields and bridges to establish the strategic regional thoroughfare from the Pacific Ocean to the Baltic Sea, and gradually move toward the set up of a network of transportation that connects Eastern, Western and Southern Asia. (Xinhua, 2013)

By reviving the Silk Road, President Xi Jinping has been working towards rejuvenation of old cultural as well as trade ties with countries along the Silk Road. At Nazarbayev University in Kazakhstan, President Xi delivered a speech titled "Promote People-to-People Friendship and Create a Better Future". During the speech, he stated: "In order to make the economic ties closer, mutual cooperation deeper and space of development broader between the Eurasian countries, we can innovate the mode of cooperation and jointly build the NSREB step by step to gradually form overall regional cooperation. First, to strengthen policy communication. Countries in the region can communicate with each other on economic development strategies, and make plans and measures for regional cooperation through consultations. Second, to improve road connectivity. To open up the transportation channel from the Pacific to the Baltic Sea and to gradually form a transportation network that connects East Asia, West Asia, and South Asia. Third, to promote trade facilitation. All the parties should discuss the issues concerning trade and investment facilitation and make appropriate arrangements. Fourth, to enhance monetary circulation. All the parties should promote the realization of exchange and settlement of local currency, increase the ability to fend off financial risks and make the region more economically competitive in the world. Fifth, to strengthen people-to-people exchanges". (Ministry of Foreign Affairs of the PRC, 2013)

According to President $\mathrm{Xi}$, one of the major goals of BRI is to "break the bottleneck in Asian connectivity by building a financing platform" (Xinhua, 2014). To achieve this objective, President Xi has divided BRI into two components: land and maritime. While the maritime component of BRI is known as the $21^{\text {st }}$ Maritime Silk Road (MSR), land component is termed as NSREB, of which the Central Asian region is a key part. Aiming to bring sixty countries on board, the Chinese government has developed a blueprint of intent, 
which has laid out the future plans for China in terms of working towards the implementation of the NSREB. This chapter, focuses on the important component of the NSREB, seeks to analyze China's motives and intent in the Eurasian landmass with a special focus on Central Asia. The paper includes following parts: China's Interests in Central Asia; Situating Central Asia in BRI; Response from Central Asia and Conclusion.

\section{CHINA'S INTERESTS IN CENTRAL ASIA}

Central Asia lies at the heart of China's Eurasian diplomacy in general, and the NSREB in particular. Following the collapse of the Soviet Union, China has endeavored to build and strengthen its relations with the five Central Asian states of Kazakhstan, Kyrgyzstan, Tajikistan, Turkmenistan, and Uzbekistan. China established diplomatic ties with the five newly independent Central Asian Republics in January 1992. Today the established cooperation between China and Central Asian states reached the strategic partnership level. China is the fourth largest in the world in terms of size and biggest non-CIS neighbor of Central Asia. It shares a border of about 3,500 km with Kazakhstan, Tajikistan and Kyrgyzstan. While originally the main focus of its political and diplomatic activities was to settle the Soviet legacy of disputed borders, its ties with Central Asia later started to reflect a growing desire to protect broader economic and security interests in the region. One of the major priorities of China is to maintain peace and stability in the region so that its own security at the border is safeguarded. Border security and Xinjiang Uyghur Autonomous Region (XUAR), which is the most restive region in China with majority of Muslim population have always been at the helm of China's Central Asia policy. According to estimates of the leaders of the Central Asian states, almost complete understanding was reached in ensuring regional security.

Also, the neighboring countries are partners in the international large-scale projects as the New Silk Road Initiative. Most of the routes from China to Europe pass through Central Asian territory, located strategically on the crossroads between Europe and Asia. As China is expanding its economic outreach to Europe, Central Asian countries wants to benefit beyond transit fees develop its infrastructure possibilities. Therefore, the major role of China in Central Asia in terms of geopolitics and geo-economics is quite understandable. According to American expert Martha Brill Olcott, China seems to have decided to move ahead of time, mentioning that the country has surpassed the United States and Russia in terms of influence in Central Asia (Olcott, 2013).

The Kazakh expert Kaukenov (2008: 83) assesses the situation as follows. China is regarded as a reliable and generous lender in many Central Asian countries and it does not attach political or democratic strings. China has put forward a number of goals, aiming to

(i) Become a regular participant in regional economic and political cooperation;

(ii) Help Central Asian countries set up barriers against the influence from external players;

(iii) Expand its cultural presence in Central Asia, which is prerequisite for China to become a superpower. 


\section{The SCO: Fighting Three Evils}

China's security relationship with Central Asia has grown manifold since the foundation the Shanghai Five Mechanism encouraged by Beijing in 1996 in order to resolve the border issues among China, Russia, Kazakhstan, Kyrgyzstan and Tajikistan. Established in 2001 the Shanghai Cooperation Organization (SCO) requires member states to develop state-to-state relationships based on partnerships rather than alliances. The SCO now has China, Kazakhstan, Kyrgyzstan, Russia, Tajikistan and Uzbekistan, India and Pakistan as its full members, with Afghanistan, Belarus, Iran, Mongolia and as observers, and Armenia, Azerbaijan, Cambodia, Nepal, Sri Lanka and Turkey as dialogue partners. Nowadays, the SCO brings together 18 states, which are inhabited by over 3 billion people or over $45 \%$ of the world population (RIA, 2016). In 2015, the GDP of the SCO member states amounted to over $\$ 21$ trillion, accounting for $27.1 \%$ of the world's total (CGTN, 2017). The SCO hints at new regional cooperation model under which member states coordinate their actions but do not have treaty obligations on specific issues, particularly in the military field. After settling border disputes, the SCO members promoted cooperation fighting with the security treats. The official founding declaration asserted that the main objective of the organization was to combat the so-called three evil forces: international terrorism, ethnic separatism and religious extremism. Thus, the SCO maintaining the safeguarding regional security and promoting regional development. The organization has been interpreted in a variety of ways since its inception. One group of analysts agree with the views of the governments of the SCO member states that the organization is primarily focused on regional security problems (Aris, 2009). Many Chinese analysts as Yu Jianhua, Director of the Institute of Eurasian Studies of the Shanghai Academy of Social Sciences (SASS) express the same view: the SCO is a regional organization of non-traditional security (Jianhua, 2009). Moreover, the Chinese Government does not consider the SCO as an alliance or bloc that could confront any third country, regional group, or organization. Therefore, Beijing insists that the SCO refused to be shaped as an anti-NATO bloc.

By initiating and developing the SCO, China started to focus on multilateral relations in its Central Asian policy rather than bilateral relations. China's main goal is the preservation of the stability, economic well-being, political order and security of XUAR, which shares a long and common border with Russia, Mongolia and three Central Asian states of Kazakhstan, Kyrgyzstan and Tajikistan. The second aim is to creating of a friendly and secure belt of states around Xinjiang region (Pradhan, 2018). The XUAR of China, sometimes known as East Turkestan or Chinese Turkestan, is home to approximately 21.6 million people of different ethnicities. The XUAR is one of the largest region in China, its shares one-sixth of the country's territory. The XUAR is economically prospering, but instability continues to persist for a range of reasons, such as Uyghurs' desire for autonomy or independence, dissatisfaction with the government, Han migration, income disparity, employment discrimination, religious suppression and resistance to assimilation (Wong-Tworek, 2015). Thus, China is more concerned with Uyghur separatism. Along with solving border issues with the Central Asian countries two Treaties on border security were signed: the Treaty on Deeping Military Trust in Border Regions (1996) and the Treaty on Reduction of Military Forces in Border Regions (1997).

The primary target of the Chinese anti-terrorism campaign is the East Turke- 
stan Islamic Movement (ETIM), which advocates for the independence of Xinjiang. From the Chinese perspective, in the framework of the SCO it is of particular importance for China to be able to count on the support of the other nine member and observer states in its campaign against the ETIM. Moreover, China has also been able to draw support from the SCO partners in its efforts to frustrate other conventional or non-conventional security threats and to eliminate or to ease the external factors of disruption to China's stability and development. By 2001, when the SCO was formed, Chinese leaders were fully convinced that multilateral regional organizations were significant mechanisms for China to articulate its interests, strengthen its influence, cultivate its soft power, and promote multipolarity. In less than a decade, China was transformed from a passive, defensive participant to an active organiser with a well-defined agenda and strategy (Cheng, 2013). Through the SCO China is keeping geopolitical balance in the "strategic hinterland" region as well as playing a key role in the establishment of new structure of regional security process legally. The program of cooperation on security issues began shortly after establishing of the SCO. At that period it was very important for China to prevent the foreign intervention into the Central Asian states policy and security, as well to avoid supporting of ETIM by the other newly independent Central Asian Turkic states. In this light, following documents were signed in the SCO framework: The Shanghai Convention on combating terrorism, extremism and separatism (2001); SCO Regional anti-terroristic structure (2002); Agreement on combating drug trafficking (2004); Agreement on joint anti-terrorist activities (2006); Treaty of the long-term good neighborly and friendly cooperation among member states of the SCO (2007); Agreement on combating trafficking in firearms, ammunition (2008); Agreement on cooperation in the field of ensuring international information security (2009); Joint declaration on cooperation between the SCO and UN secretariats (2010); Provision on the political, diplomatic measures and mechanisms for regulating the situations that endanger security and stability of the region (2012). Also, the Peaceful Mission - a joint anti-terroristic military exercises were first time kicked off within the SCO framework in 2002. The member-state military units practiced a joint anti-terrorist operation in the SCO territory annually. Combat units have worked out actions to confront terrorists on land, at sea and in the air. All these agreements provided legislative base for the SCO common security space and adopted political and military measures, building an unpredictable cooperative and stronger relationships within the regional community. Also, through the security cooperation the SCO passed the institutionalization process.

\section{Energy}

China's interest in the region's resources serves the primary purpose of meeting its growing domestic energy needs. Economic reforms in the 1970s and 1980s in China resulted in rapid economic growth, boosting the demand for energy and turning the country into a net importer. Although China has been importing crude oil since 1993, it has been unable to meet its gas needs on its own since 2006, and has been actively searching for alternative energy supplies. Counting on newly explored Central Asian resources, China attempted first to diversify its energy imports by sources and routes, and second to actively participate in the development of new gas fields (Aminjonov, 2018). International Energy Outlook 2016 estimates that in 2015, China's oil imports amounted to about 6.6 million barrels per day, 
which was $59 \%$ of the country's total oil consumption (Sternberg et al, 2017). Eurasian By 2035, the Energy Information Administration (EIA) projects China's oil Journal imports will rise to about 9.7 million barrels per day, accounting for about voluary 2019 $62 \%$ of total oil consumption (Mariani, 2013). It is necessary to note, that in the context of the global financial crisis, China has become the largest creditor and the investor for Central Asia, almost bypassing both Russia and the countries of the West. Thus, China and Central Asia share common interests in the economics and politics field. Central Asia supplies hydrocarbons so necessary for China and it is ready to become the trade bridge between China and the Western Europe. China's elite have determined Central Asia as an ultimate bridge linking the mainland with the main BRI land points, thus, positioning it as one of Eurasia's most promising centers and making it a prime location for observers. It is clear that a key goal for Chinese investors in Central Asia is to secure overland deliveries of energy resources to China by inland routes alternate to maritime shipments, which means that Beijing also has a geopolitical interest in strengthening energy cooperation with Central Asia. Therefore, China has been keen on developing energy corridors in Central Asia. Presently, China is the second consumer of oil and gas in the world and may be importing 50\% of the regions oil by 2020 China's major energy partners in Central Asia are Kazakhstan and Turkmenistan with whom it shares a 1,700 km land border. As of August 2016, China is in control of $20 \%$ of the Kazakh oil production and has constructed one of the world's longest pipelines running about 2, $300 \mathrm{~km}$ from the Caspian Sea to the Xinjiang province (Hart, 2016). The cooperation and economic foundations between China and Central Asia are extensive and sound, and urgency for policy cooperation in energy transit can be seen. At present, transit projects between China and Central Asia include the China-Kazakhstan oil pipelines, China-Kazakhstan gas pipelines (the second phase of the China-Central Asia gas pipelines), and the China-Central Asia gas pipelines. The China-Central Asia Gas Pipeline is the most important line for importing energy to China and falls into four sub-pipelines: lines A, B, C and D.

China already has arrangements with Central Asia through three operational China-Central Asia Gas pipelines. The pipeline starts at Turkmen-Uzbek border city of Gedaim and runs through Central Uzbekistan and southern Kazakhstan before reaching Horgos Special Economic Zone and Xinjiang. Lines A and B were inaugurated in 2009 and 2010. Line C was completed at the end of 2013 and was inaugurated in May 2014. It was constructed along the same route as lines $A$ and $B$, with a total length of $1,830 \mathrm{~km}$. The designed capacity is $25 \mathrm{bcm}$ annually, of which Turkmenistan will supply 10 bcm, Uzbekistan 10 bcm and Kazakhstan 5 bcm. In September 2013, an inter-governmental agreement was signed between China and three Central Asian states (Kyrgyzstan, Tajikistan and Uzbekistan) to start construction of Line D. Line D follows a different route compared to lines $A, B$ and $C$. It will pump gas from fields in eastern Turkmenistan through Uzbekistan, Tajikistan and Kyrgyzstan to the Chinese border (Wang 2016). Therefore, the reliability of energy supplies, along with interdependencies within diversified export routes, requires an effective regional energy governance mechanism to be established either within the SCO or the BRI (Aminjonov, 2018).

\section{China's Peaceful Co-development and Good Neighborly Policy}

After the settlement of the boundary issue, China signed the good-neighborly treaties of friendship with three neighboring Central Asian countries. 
In 2002, China signed the China-Kyrgyzstan Good-neighborly Treaty of Friendship and Cooperation with Kyrgyzstan and signed China-Kazakhstan Good-Neighborly Treaty of Friendship and Cooperation with Kazakhstan. China and Tajikistan signed the China-Tajikistan Good-neighborly Treaty of Friendship and Cooperation in 2007. The Treaty of Long-term Good-neighborly Relations, Friendship and Cooperation among then the Member States of the SCO was approved in the $7^{\text {th }}$ Summit of leaders of SCO members held in Kyrgyzstan in 2007 (Enyuan, 2012). China's emerging role in the international arena triggers a change in current international political environment and causes further rebalancing of multipolar system. Therefore, strengthening multilateral cooperation with the other regional powers and international organizations provides suitable atmosphere for development of China's New Diplomacy. The basis of China's New Diplomacy is formed by the New Security Concept, the New Development Approach, and the New Civilization Outlook, which were introduced in early 2000s. China's New Diplomacy has first been visible in China's diplomacy towards the Asian region, because the neighboring countries have always been crucial for Beijing to create a favorable and stable international environment. The New Security Concept encourages nations to build trust through consultations and to seek national security by means of multilateral coordination. It emphasizes: (1) multilateral ties, which stress interdependence among nations in terms of security; (2) cooperation, which replaces confrontation as the effective route to security; (3) comprehensiveness of security, which is not only confined to military and political fields alone, but also includes economic, technical, social and environmental fields; (4) institutional construction, as the legitimate road to security. The New Security Concept rejects power politics and the Cold War thinking. Proposed at the forum of the Central Committee of China's Communist Party in March 2004, by the President Hu Jintao, the New Development Approach stated that all countries should strive to achieve mutual benefit and "win-win" situations in their pursuit of development. Moreover, the New Civilization Outlook as a part of Hu Jintao's concept of the Harmonious word encourages intercivilization dialogue and aims at building a harmonious world on the basis of equality (Antonescu, 2015). The key idea of the Concept is that each civilization has the inalienable right to choose its own and independent development path, which is suitable for its own conditions. Since 1990s China sees its neighbors as partners and friends, not as adversaries and enemies; the purpose of the overall Chinese diplomacy towards its neighbors is to foster stability in the neighborhood and reduce suspicion and fear.

\section{SITUATING CENTRAL ASIA IN BRI}

The coconstruction of the BRI project is one of the major goals of Chinese Government. Despite the creation of the Eurasian Economic Union (EEU), China remains the major trade partner of Kazakhstan. Within the BRI, the two countries are developing infrastructure facilities for bilateral trade. Consequently, the EEU, a regional organization, initially created aiming to protect itself from an excessive economic influence of China, has changed its direction toward the interface with the Chinese initiative. BRI's primary goal is to create a system to facilitate Chinese outbound investment, which is necessary in order to maintain country's economic growth as it transits into a more mature and developed economy. As explained by Dr. Pang Zhongyin (2015), currently the Dean of the School of International Studies at the Sun Yat-Sen University, an ultimate impact of China is to be a "Renewed World 
Order", where the real-sector trade would replace financial control over the world economy and where strength is returned to multilateral institutions such as the UN and sovereign states, just as it was supposed to be after the World War II. Dr. Pang added more contextual clarity by describing BRI's economic genesis as being the natural progression from interdependency to globalization and now to connectivity, which he forecasts will ultimately lead to next generational global economic governance through the creation of a worldwide free trade road map.

This project is a major initiative for China to carry out open economic policies under new geopolitical conditions and it is also the most important project that China expects to provide special benefits for the Eurasian region. Central Asia is the historic core of silk roads through time. Today, presented as an economic corridor, a BRI of pipelines, bridges, roads, etc. is imagined for Central Asia to enhance security and energy cooperation. The Chinese side could manage to set financial provision mechanisms within the framework of the BRI. Several institutions were established to finance the Chinese BRI. The first institution is the Silk Road Fund with $\$ 40$ billion capital, which is planned to be increased up to $\$ 100$ billion. The second institution is the Asian Infrastructure Investment Bank (AIIB), established with $\$ 100$ billion fund. The third institution is the New Development Bank BRICS (NDP BRICS). The total amount of funds of these three institutions could reach $\$ 240$ billion. The AIIB started operations in January 2016, and the first group of projects financed by the Silk Road Fund has been officially launched. The Economist (2015) reports that China plans to spend a total of $\$ 1$ trillion in government funds through AIIB and the China Development Bank on the BRI. Nowadays, countries along the route are discussing the possibility of allocation of mentioned funds for establishment or expansion of bilateral and multilateral cooperation. The BRI have gained wide international acceptance since the number of its participants has increased gradually. About 70 countries and organizations have expressed their support and contribution to the project. This global support has exceeded the scope of the traditional BRI project and helped to form an international cooperation framework with broad influence. Meanwhile, 34 countries and international organizations have already signed a number of inter-governmental cooperation agreements with China on jointly building the BRI project. Based on these inter-governmental cooperation agreements, specified cooperation programs will be additionally formulated. The Chinese Foreign Minister, Wang Yi, and the United Nations Economic and Social Commission for Asia and the Pacific (UNESCAP) Executive Secretary, Shamshad Akhtar, signed the letter of intent in Beijing on April 11, 2016. According to the document, the two sides will jointly promote regional cooperation and the implementation of the BRI initiative. The two sides will also make specific action plans and encourage relevant countries to synchronize their development strategies with the initiative. Currently the BRI is at the stage of transforming from being discussed to being accepted to a certain level both economically and politically. To date, the BRI countries could manage to avoid the direct conflict of interest formally reaching an agreement on their participation in the project. However, with transition to the implementation phase, there is an essential need for the approval of the Official BRI Action Plan, according to which the BRI funds will be allocated.

Continental infrastructure development is one of the key goals of the NSREB, a transportation network is gradually taking its final shape within the framework of the initiative. 


\section{Why Central Asia is Important for BRI?}

China has been discussing the reviving of the Ancient Silk Road with Eurasia as a main direction since the Soviet Union collapse. Eventually, Chinese government has been investing fundamentally in infrastructure development and logistics projects for the past two decades. The then Chinese Premier, Li Peng stated the concept of the revival of the Ancient Silk Road during his maiden visit to Central Asian states. He said that "it is important to open up a modern version of the Silk Road" (Karibzhanov et al, 2012). Central Asia is placed highly in China's priority with respect to BRI. The out of five Central Asian states shares a long border with China. Given its strategic location, Central Asia is one of the most important region for BRI, since BRI treats Asia and Europe as a single space. Most of the routes from China to Europe pass through Central Asian broad territory, located strategically on the crossroads between Europe and Asia. As China is expanding its economic outreach to Europe, Central Asia wants to benefit beyond transit fees as it is trying to break away from oil and gas dependence. Also, Central Asian states come under the category of countries that are (overtly) friendly towards China. Therefore, China's influence in Central Asia has been on the rise, Russia is still dominant power. BRI will allow China to increase its presence in Central Asia. Nowadays, Central Asia is one of those regions of the world where security issues are always on the agenda. In the international community the Central Asian region is still associated with drug trafficking, danger of religious extremism and terrorism, and the underdevelopment of political and civil institutions. To this day, five countries in the region are still not in the position to regulate the arising problems finally (Somzhurek et al, 2018). Thus, initiating the BRI, China not only boosting cooperation with the Central Asian countries and strengthening the political and economic links, but also contributing into stability and security in the region.

\section{Main BRI Projects in Central Asia}

The Central Asian route's popularity has origin in China's spectacular growth. China began to re-emerge as an exporting power in the 1980s, and now exports $\$ 2$ trillion of products per year across all routes, with roughly $\$ 500$ billion of that to Europe and $\$ 15$ billion to the five Central Asian countries (Observatory of Economic Complexity, 2015). A spokesperson for the Chinese Ministry of Commerce noted in April 2017 that since 2013, \$304.9 billion in contracts have been signed between China and the economies along the route (Xinhua, 2017a). Following are the two major land economic corridors proposed under the BRI for Central Asia.

\section{The New Eurasian Land Bridge}

China's rail system has long linked to the Trans-Siberian rail system through northeastern China and Mongolia. In 1990, China added a link between its rail system and the Trans-Siberian system via Kazakhstan. China calls its uninterrupted rail link between the port city of Lianyungang and Kazakhstan the New Eurasian Land Bridge or the Second Eurasian Continental Bridge. In addition to Kazakhstan, the railways connect with other countries in Central Asia and the Middle East, including Iran. Since the completion of the rail link across the Bosphorus under the Marmaray project in October 2013, the New Eurasian Land Bridge has been connecting to Europe via Central and South 
Asia. The new Eurasian Land Bridge is a transport route linking the Pacific Ocean to the Atlantic Ocean. Unlike the Trans-Siberian Railway starting from Vladivostok through Siberia to Moscow and further to Western Europe, this new bridge operates from the coastal city of China Lianyungang to Rotterdam (Netherlands) and Antwerp (Belgium). The railway route with the length of 10,800 km will pass through Kazakhstan, Russia, Belarus, Poland and Germany and will operate in more than 30 countries and regions. At the moment, several transcontinental railway routes already started operating, showing the potential of the BRI. Including the routes of Chongqing - Xinjiang - Europe / Duisburg, Germany /, Chengdu - Xinjiang - Europe / Poland / and Yiwu - Xinjiang - Europe / Madrid/. Now, the construction of appropriate roads, power lines and ports is steadily progressing.

$12875 \mathrm{~km}$ route, from the city of Yiwu in Zhejiang province to Madrid, is the longest continuous train route ever. Many slightly different routes have been labeled under the term of the New Eurasian Land Bridge - some link Chongqing to Duisburg, while others link Beijing to Hamburg, however it is the middle section of the route, from Kazakhstan to Poland, which seems to define it. Rail freight from China to Europe is growing. Container traffic on the Trans-Siberian railway grew by $15 \%$ in 2013 and $22 \%$ in 2014, with a total of 865,60020 -foot (6.1 meters) containers of freight in the first six months of 2014. The average container spent 14 days in transit, confirming industry claims on the speed of China-Europe rail freight transit (Kondapalli, 2017). While Kazakhstan might have been overly optimistic in predicting a tripling of freight traffic through Kazakhstan every year from 2013 to 2020 (Bradsher, 2013), further growth does seem likely as the early movers solve logistical problems on the route, making newer entrants' issues less pronounced (Debreczeni, 2015).

\section{Economic Corridor China - Central Asia - Western Asia}

According to the Chinese Xinhua (2017b) news agency, the Economic Corridor China - Central Asia (ECCCA) links China and the Arabian Peninsula. The vast region, which it covers, actually repeats the trajectory of the ancient Silk Road. The corridor starts from China's Xinjiang and traverses Central Asia before reaching the Persian Gulf, the Mediterranean Sea and the Arabian Peninsula. It crosses five Central Asian countries (Kazakhstan, Kyrgyzstan, Tajikistan, Uzbekistan and Turkmenistan) and 17 countries and regions in West Asia (including Iran, Saudi Arab and Turkey).

Kazakhstan is one of the best examples of the BRI cooperation in Central Asia. The Lianyungang terminal, which is located at the Jiangsu Province in East China, is Kazakhstan's first exit to the Pacific Ocean. The Lianyungang joint terminal is aimed to increase the export and import, as well as transit potential of Kazakhstan by railways, providing the shortest way to the Asia-Pacific region and South East Asia. The project contributes to the development of trade relations in the region and creates the possibility of transit from these countries to Central Asia, the Gulf States, Russia, the Caucasus region and Europe through the territory of Kazakhstan. About $60 \%$ of Kazakhstan's trade with East and South-East Asia countries along the BRI is carried out through the port of Lianyungang, through the new Eurasian continental bridge. Lianyungang is a key hub for Kazakhstan's trade with the East. Chinese "Lianyungang Port" Group and "Kazakhstan Temir Zholy Express" LLC jointly participated in the construction of the logistics cooperation project, 
where Kazakhstan shares 49\% and China - 51\%. In total, \$99.4 million were invested in the project (Surganov, 2015). The construction of the first joint Kazakh-Chinese terminal was laid in 21 hectares territory on May 2014. Container terminal of 200 thousand square meters, 1763 Container Parks, warehouse-unpacking containers in the area of 23 thousand square meters and $3.8 \mathrm{~km}$ access road terminal were constructed. The average daily throughput is 10.2 trains. Currently the highest annual truck capacity is 410 thousands of standard containers. Moreover, it is expected that by 2020, the terminal will process over 550 thousands of containers per year. The Lianyungang logistics cooperation project was created to implement a comprehensive international transportation, unpacking of the container orders, warehousing and other international cargo transportation. From January to November 2016, import and export volume of bilateral goods between Kazakhstan and China in the amount of $\$ 7.08$ billion declined by $24.7 \%$. Thus, Kazakhstan's exports to China amounted to $\$ 3.82$ billion, declining by $23.9 \%$, averaging $12.1 \%$ of its total export; Kazakhstan's imports from China amounted to $\$ 3.16$ billion, down by $31.2 \%$, averaging $23.1 \%$ of its total import. By November 2016, China has become Kazakhstan's second largest export market and the largest source of imports (Kazakhstan Trade Newsletter, 2016). Kazakhstan mainly imports clothes, electrical and mechanical equipment, construction materials, furniture, steel, etc. from China. Kazakhstan primarily exports oil and gas, non-ferrous metals, alluvial ore, grains, live leather, cotton, etc. to China.

From January to November 2016, Kazakhstan's cargo import and export reached $\$ 4.8$ billion, and increased by $21.7 \%$. Among them, the export in the amount of $\$ 3.32$ billion increased by $33.6 \%$; imports totaling to $\$ 1.48$ billion increased by $1.5 \%$. Trade surplus amounted to $\$ 1.84$ billion, increasing by $78.7 \%$. Cargo trains have already begun running from China to Iran through the territory of Kazakhstan and Astana is hoping to modernize its own available locomotives and repair $740 \mathrm{~km}$ of rails. The project's total cost is to amount to $\$ 2.7$ billion; by making the upgrade, Kazakhstan aims to capture $10 \%$ of the $\$ 600$ billion trade volume between China and Europe. The government of Kazakhstan has launched several programs including the "2050 strategy" and the "100 concrete steps" that incorporate the Chinese investments and goals for realignment with the BRI. In effect, trade turnover between the two nations has surpassed $\$ 18$ billion and keeps growing, turning China into Kazakhstan's major strategic partner (Xiao, 2018). Beijing has also already invested nearly $\$ 30$ billion in the country's mining, oil, transport, and agricultural sectors. These investments add to Astana's own $\$ 9$ billion stimulus plan for the nation's modernization. Furthermore, Astana is also constructing "special economic zones" that include the Khorgos "dry port" on the Kazakh-Chinese border. On November 25, 2011, the Kazakh government decided to establish the Khorgos-East Gate logistics center near the Khorgos "special economic zone" (Frolovskiy, 2016).

Kazakh President Nursultan Nazarbayev and Chinese President Xi Jinping attended the opening ceremony of the first stage of the Kazakhstan logistics terminal in the Lianyungang port on May 19, 2014. The first train carrying 720 tons of wheat from Kazakhstan arrived in the Lianyungang port on February 5, 2017. It was then shipped to Southeastern Asia, opening a new trade route. Transit cost of Kazakhstan's trade with East Asia significantly reduced, saving about $\$ 72$ million per year. Thus, the distance to Japan shortened by 2,500 km and by 3,900 km to Singapore, comparing with the first Eurasian Continental Bridge route. Kazakhstan mainly imports vehicles and its parts, mechanical equipment, electrical appliances, plastic and rubber from East and Southeast Asia (Kulintsev, 2015). Chinese side made pro- 
posals on joint construction of the "Integrated Bonded Area New Area in Suwei district of Lianyungang". The Bonded Suwei New Area is supposed to join Kazakhstani and Chinese producers. In particular, the processing and modification of copper products, food, household goods, electronics, second-hand goods and vehicles are exported from Kazakhstan to North-East Asia. The Bonded Suwei New Area will supply exporters with technical support. Therefore, construction of the "Business complex", the "Asia-Europe trade and exhibition center", the "trade and service street" and other projects are planned. Among them, the total area of the SCO Countries Logistics Zone terminal will cover 450 hectares, where joint "State trading complex" will be constructed. According to the "Integrated Bonded Area New Area in Suwei district of Lianyungang" plan, Special-Customs-Control-Area will be established by 2030. The Lianyungang Customs is located in harbor area of Lianyungang. Nowadays, it has set up 16 section offices, including supervision office, technological office, and customs clearance office and so on, and one functional office, one anti-smuggling branch comprised of eight offices. At present, its jurisdiction covers the whole city of Lianyungang (Lianyungang Customs District, 2014). China's elite have determined Lianyungang as an ultimate bridge linking the mainland with the maritime portions of the BRI, thus, positioning it as one of Eurasia's most promising cities and making it a prime location for observers. Since it is also anticipated to play a bimodal (land and sea) role in linking the other regions of the extended supercontinent alongside it's near limitless physical infrastructure development potential, Lianyungang is easily predicted to become the center of geo-economic gravity that holds the BRI together, and likewise, one of the world's most critical economic fulcrums in the coming decades. During the $12^{\text {th }}$ meeting of Heads of Governments (Prime Ministers) of the SCO member states on November 29, 2013 in Tashkent, the Prime Minister of the State Council of China, Li Keqiang, stated that Lianyungang city, located in the eastern beginning of the new Eurasian Continental Bridge, would give the member states of the SCO an access to logistics services and warehousing (The Regional Anti-Terrorist Structure of SCO, 2013).

\section{Response from Central Asia}

China is focused on how the BRI was perceived in Central Asia and other countries directly involved in the project and how these perceptions shaped responses to the initiative. It is obvious that China is aware of, the spread in the whole world, the "China threat" thesis, which became visible after growth of China's economic power and military capabilities. Currently, China set the task to neutralize the negative reaction abroad to the grand integrative initiative - the BRI, through formation of a positive international image of the country. One of the areas of impact of the "soft power" of China in the region is the education system. Chinese investments into the education sector (including scholarships) increase the student acceptance rate into the Chinese colleges and universities, as well as the rate of sending students to study in universities of Central Asia, opening of the Confucius Institutes and active promotion of the study of the Chinese language. As a result, over the past 10 years the number of students from the Central Asian countries in China increased dramatically, and Kazakhstan is the leader among them. Chinese institutions and organizations in Central Asia are organizing and funding a variety of cultural (concerts, exhibitions, etc.) and scientific events (conferences, workshops, research projects), cooperating with local organizations and institutions aimed at discussion and clarification of the Chinese BRI initiative. 
To set some context for how BRI is and will be received on the ground in Central Asia, it is important to note key socio-cultural dynamics in the region. Kyrgyz and Kazakhs are Turkic nationalities with shared linguistic, religious, and cultural roots from across what was once called Turkestan, a vast area stretching from the Tibetan Plateau and Himalayas to the Caspian Sea and Turkey. Identity, kinship, spiritual practices, and lifestyles remain vastly different from that of the Han Chinese. In the Soviet era, there was a massive influx of other ethnic groups into the region, including millions of Russians and significant numbers of Ukrainian, German, and Korean immigrants. More than 3.5 million Russians remain in Kazakhstan and Kyrgyzstan, further differentiating the people and orientation of the region from China. Today this contributes to separation and animosity between local residents and incoming Chinese with fear of de facto economic appropriation expressed in major cities. Government to government relations are strong, but as 2016 protests of perceived Chinese land-grabs in Kazakhstan demonstrated, these may not be attuned to local sentiments. Thus, as BRI projects are initiated, citizen interest and acceptance needs to be considered and addressed (Sternberg et al, 2017).

\section{CONCLUSION}

Through BRI, China is and will certainly remain the largest investor in Central Asia. It is the only country that can mobilize huge investment in the region, far beyond what Western countries and Russia can offer. China's growing involvement in Central Asia is a long-term phenomenon and a turning point in Central Asia's post-Soviet history and economic development (Laruelle, 2018). Central Asia is a key region to ensure the economic growth of XUAR and the development of the land corridor between China and Western countries as an alternative to the sea routes. At the moment, Central Asian countries are open to Chinese investment, but how successful the implementation of the BRI in Central Asia will depend on many factors in the medium and long term.

According to Xi Jinping's statement delivered at the $19^{\text {th }}$ National Congress of the Communist Party of China on October 18, 2017, the Chinese government assesses the situation as follows: "China adheres to the fundamental national policy of opening up and pursues development with its doors open wide. China will actively promote international cooperation through the Belt and Road Initiative. In doing so, we hope to achieve policy, infrastructure, trade, financial, and people-to-people connectivity and thus build a new platform for international cooperation to create new drivers of shared development" (Xi Jinping, 2017).

China's economic influence and soft power has been commendable considering the short span of time in which China has strengthened its relations with Central Asia. In conclusion, it may be argued that through BRI, China seeks to develop its western region and reap economic benefits. Also, China is concerned on ties with the Central Asian region and whole Eurasia due to its global geopolitical ambitions. Developing of infrastructure projects within the BRI in Central Asia gives logistical diversification both for Central Asia and China. Ongoing implementation shows that Central Asia figures as one of the key strategic partner of the project and hold a significant place in the China's plan. 


\section{REFERENCES}

Ai, Yan (2017). "SCO to Expand For First Time in 2017 Summit". (Accessed on 20.11.2017).

Aminjonov, Farkhod (2018): Central Asian Gas Exports Dependency, The RUSI Journal 163(2).

Antonescu, Madalina (2015). "The New Chinese Security Concept and the Peaceful Rise of China as Two Basic Pillars of the Contemporary Chinese Foreign Policy". Polis 1(1): 59-77.

Aris, Stephen (2009). "The Shanghai Cooperation Organization: "tackling the three evils". A regional response to non-traditional security challenges or an anti-Western bloc?" Europe-Asia Studies 61(3): 457-482.

Bradsher, Keith (2013). "Hauling New Treasure along the Silk Road". The New York Times. (Accessed: 25.10.2018).

Cheng, Joseph (2013). "China's Regional Strategy and Challenges in East Asia". China Perspectives 2: 53-65.

Debreczeni, Gabor (2016). "The New Eurasian Land Bridge Opportunities for China, Europe, and Central Asia". The Public Sphere.

Enyuan, Wu (2012). China - Russia, Central Asia East Europe Relations: Review and Analysis. Beijing: Social Sciences Academic Press.

Frolovskiy, Dmitriy (2016). "Kazakhstan's China Choice". The Diplomat. (Accessed: 05.11.2016)

Hart, Michael (2016). "Central Asia's Oil and Gas Now Flows to the East". The Diplomat (Accessed: 14.10.2016).

Jianhua, Yu (2009). Studies on the Nontraditional Security of the Shanghai Cooperation Organization. Shanghai: Academy of Social Sciences Press.

Karibzhanov, Zhanibek and Nabizhan Mukhametkhanuly (2012). China's Foreign Policy and Kazakhstan Relationship (2000-2010). Almaty: The Kazakh University Press: 138.

Kaukenov, Adil (2008). Features of Chinese Diplomacy in Central Asia: a view from Kazakhstan. "Central Asia - China: conditions and perspectives of cooperation" conference proceedings. Almaty, KISI under the President of the Republic of Kazakhstan.

Kazakhstan Trade Newsletter (2016). (Accessed: 24.05.2017).

Kondapalli, Srikanth (2017). One Belt, One Road: China's Global Outreach. New Delhi: Pentagon Press.

Kulintsev, Yury (2015). "One Belt, One Road: an initiative with Chinese characteristics". russiancouncil.ru. (Accessed: 29.01.2017).

Laruelle, Marlene (2018). China's BRI and its impact in Central Asia. Central 
Asia Program, The George Washington University.

Lianyungang Customs, "Lianyungang Customs District of China". (Accessed: 13.12.2017)

Mariani, Bernardo (2016). "China's role and interests in Central Asia". Saferworld. Policy Brief 1.

Ministry of Foreign Affairs of the PRC (2013). "President Xi Jinping Delivers Important Speech and Proposes to Build a Silk Road Economic Belt with Central Asian Countries". (Accessed: 29.12.2017).

Observatory of Economic Complexity (2015). (Accessed: 23.10.2016).

Olcott, Martha (2013). China's Unmatched Influence in Central Asia. Carnegie Endowment for International Peace.

Ramakrushna, Pradhan (2018). "The Rise of China in Central Asia: The New Silk Road Diplomacy". Fudan Journal of the Humanities and Social Sciences 11(1): 9-29.

Somzhurek, Baubek, Aigul Yessengaliyeva, Zhanar Medeubayeva, Baurzhan Makangali (2018). "Central Asia and Regional Security". Communist and Post-Communist Studies 51(2): 161-171.

Sternberg, Troy, Ariell Ahearn and Fiona McConnell (2017). "Central Asian 'Characteristics' on China's New Silk Road: The Role of Landscape and the Politics of Infrastructure School of Geography", Land 6(3): 1-16.

Surganov, Valeryi (2015). "Lianyungang Port to Increase Cargo Traffic through Kazakhstan". (Accessed: 29.09.2015).

Wang, Han (2016). "Towards a cooperative framework for a China-Central Asia energy transit community". Occasional Paper Series. Energy Charter Secretariat Knowledge Centre.

Wong-Tworek, Susan (2015). China's Economic Development Plan in Xinjiang and How it Affects Ethnic Instability. Master's Thesis. Monterey: Naval Postgraduate School.

Xi, Jinping (2017). Secure a Decisive Victory in Building a Moderately Prosperous Society in All Respects and Strive for the Great Success of Socialism with Chinese Characteristics for a New Era Delivered at the 19th National Congress of the Communist Party of China. October 18, 2017.

Xiao, Zhang (2018). "Trade Turnover between Kazakhstan and China Amounted to $\$ 18$ billion", (Accessed: 20.09.2018).

Xinhua (2013). "Xi Suggests China, Central Asia Build Silk Road Economic Belt". September 7, 2013, (Accessed: 10.10.2016).

Xinhua (2014). "APEC Members Agree on Connectivity Blueprint". November 18, 2014, (Accessed: 24.11.2014).

Xinhua (2017a). "Belt and Road Initiative Exceeds Initial Expectations". April 
11, 2017, (Accessed: 04.12.2018).

Eurasian

Xinhua (2017b). "China-Central Asia-West Asia Economic Corridor (The Belt and Road Initiative)". April 19, 2017, (Accessed: 16.10.2018). 